\title{
Antioxidant Activity of Ethanol Extract of Polygonum pulchrum Blume
}

\author{
Asman Sadino ${ }^{1}$, Idin Sahidin ${ }^{1}$, Wahyuni Wahyuni²
}

${ }^{1}$ Department of Natural Products Chemistry, Faculty of Pharmacy, Halu Oleo University, Kendari, South East Sulawesi, Indonesia

${ }^{2}$ Department of Pharmacology and Toxicology, Faculty of Pharmacy, Halu Oleo University, Kendari, South East Sulawesi, Indonesia

\begin{abstract}
The use of antioxidants from natural resources has attracted increasing interest. One of the plant that was empirically used as an antioxidant dietary supplement was Polygonum pulchrum Blume ( $P$. pulchrum Blume). This study aimed to investigate antioxidant activity of roots, stems, leaves and flowers ethanol extract of $P$. pulchrum Blume. The extract was obtained by maceration method using ethanol solvent. Antioxidant activity was determined with 1,1-diphenyl-picrylhydrazyl (DPPH) method. We found that ethanol extracts of P. pulchrum Blume roots and stems had strong antioxidant activity with $\mathrm{IC}_{50}$ values of $25.2 \mathrm{mg} / \mathrm{l}$ and $43.26 \mathrm{mg} / 1$, respectively. Ethanol extract of flowers had the weakest antioxidant activity with $\mathrm{IC}_{50}$ value of $202.96 \mathrm{mg} / \mathrm{l}$. Vitamin $\mathrm{C}$ had very strong antioxidant activity with $\mathrm{IC}_{50}$ value of $3.97 \mathrm{mg} / \mathrm{l}$. In conclusion, this study revealed that ethanol extract of $P$. pulchrum Blume roots and stems had strong antioxidant activity, therefore, this plant might be potential as an excellent source for natural antioxidant agents for medical application.
\end{abstract}

Keywords: Polygonum pulchrum Blume, DPPH, antioxidant, maceration, ethanol

\section{Introduction}

The use of antioxidants derived from plants have widely improved around the world. Many plants contain various phytochemicals which possess antioxidant activity to protect cells from damaging effects of reactive oxygen species (ROS), such as superoxides, peroxyl radicals, hydroxyl radicals and peroxinitrins. $^{1,2}$
In human, production of ROS as the result of biochemical process might increase with several factors, including toxins and chemicals in food, pollutants, radiations, etc. Antioxidants compounds are needed to tackle this problem. However, synthetic antioxidant compounds such as butylated hydroxytoluene and hydroxyanisole might cause various side effects. ${ }^{3}$ This encourage researchers to find

Corresponding author: Asman Sadino, Department of Natural Products Chemistry, Faculty of Pharmacy, Halu Oleo Univer-

sity, Kendari, South East Sulawesi, Indonesia. Email: asmansadino51@gmail.com

Received: 20 May 2016. Revised: 8 July 2016. Published: 1 August 2016 
alternative treatments, particularly from natural source.

One of the plants that has a potential to be developed as a natural antioxidant is Polygonum pulchrum Blume (P. pulchrum Blume). This plant is widely spread around the Asian-African continents, including India, China, Malaysia, Myanmar, Srilanka, Thailand and Indonesia. ${ }^{4}$ This plant is known as ketapan or kumpai air in Indonesia.

Previous studies showed that several plants from Polygonum family had antioxidant, antibacterial, and hepatoprotective activities..$^{5-7}$ However, limited information was available regarding biological activity of P. pulchrum Blume. Therefore, this study was performed to investigate antioxidant activity of root, stems, leaves and flowers ethanol extracts of $P$. pulchrum Blume.

\section{Methods}

Instruments and materials

The instruments used in this study were rotary vacuum evaporator (Buchi $\left.{ }^{\circledR}\right)$, hot plate (Stuart $\left.{ }^{\circledR}\right)$, UV-Vis 20D (Thermo ${ }^{\circledR}$ ) spectrophotometer, analytical scales (Precisa $\left.{ }^{\circledR}\right), \quad$ blender $\quad$ (Philips $\left.{ }^{\circledR}\right), \quad$ vortex (Stuart ${ }^{\circledR}$ ), cuvette (Hellma analytics ${ }^{\circledR}$ ), micropipette (Eppendorf $®)$, stirring rod, vial, volumetric flask (Pyrex $\left.{ }^{\circledR}\right)$, TLC plate GF254 (Merck $\left.{ }^{\circledR}\right)$, UV lamp (Srahlen Germany ${ }^{\circledR}$ ), chamber, capillary pipes. Materials used included ethanol 96\% (Merck $\left.{ }^{\circledR}\right)$, vitamin C (Braco $\left.{ }^{\circledR}\right)$, and 1,1-diphenyl-picrylhydrazyl $(\mathrm{DPPH})$ reagent. Roots, stems, leaves and flowers of $P$. pulchrum Blume was obtained

Table 1. Yield of extract

\begin{tabular}{llccc}
\hline Sample & & Powder sample (g) & Viscous extract (g) & $\begin{array}{c}\text { Yield percentage } \\
\text { (\%) }\end{array}$ \\
\hline P. pulchrum Blume & Roots & 553 & 18 & 3.6 \\
& Stems & 800 & 25.5 & 5.1 \\
& Leaves & 700 & 16.2 & 3.24 \\
& Flowers & 750 & 11.5 & 2.3 \\
\hline
\end{tabular}

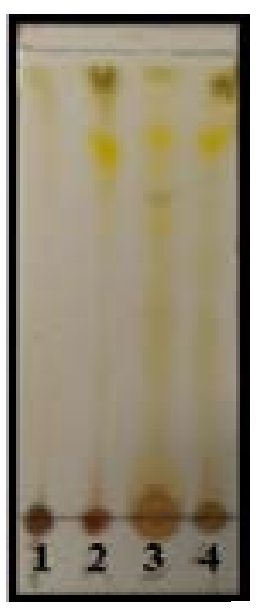

(a)

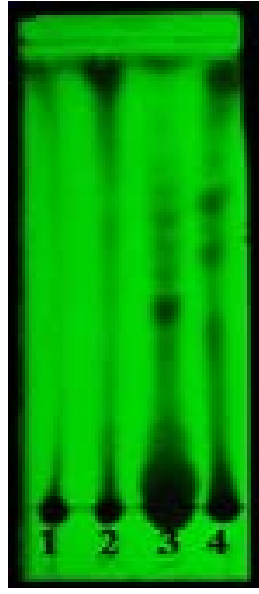

(b)

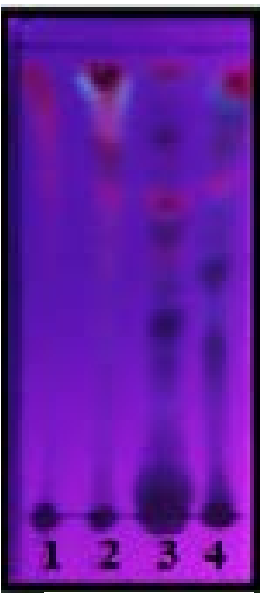

(c)

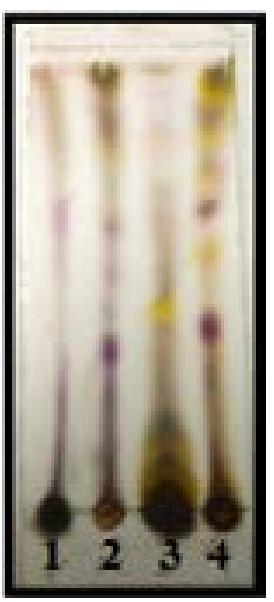

(d)

Figure 1. Phytochemical screening result (a) elution result (b) UV-254 nm (c) UV-366 nm (d) TLC with heating process. (1) roots (2) stems (3) leaves (4) flowers 
solvent. Separation of residue and filtrate was performed every $1 \times 24$ hours accompanied by the same solvent replacement to obtain the filtrate. The filtrate was collected and concentrated using a rotary vacuum evaporator at a temperature of $58^{\circ} \mathrm{C}$ to obtain a viscous extract.

Phytochemical screening using thin layer chromatography (TLC)

The phytochemical screening test with TLC was performed using silica gel plate GF254. The mobile phase used were chloroform and methanol (9:1). The developers and test reagents were as follows: the alkaloid using the Dragendorff reagent (orange), the flavonoid using the $0.1 \mathrm{~N} \mathrm{NaOH}$ reagent (yellow) and sodium carbonate reagent (green, yellow), tannin using $1 \% \mathrm{FeCl}_{3}$ reagent (black/blue), saponins using $\mathrm{H}_{2} \mathrm{SO} 4$ reagent (dark purple), violin triterpenoids using Lieberman-Burchard reagent (violet red). ${ }^{8}$

\section{Antioxidant activity}

Preparation of DPPH reagent $40 \mathrm{mg} / \mathrm{ml}$

$2 \mathrm{mg}$ of DPPH were weighed and dissolved in ethanol until all dissolved. It was then added with $50 \mathrm{ml}$ ethanol. The solution was shaken until homogeneous.

\section{Preparation of blank solution}

The preparation of the blank was performed by reacting $1 \mathrm{ml}$ of $40 \mathrm{mg} / \mathrm{l} \mathrm{DPPH}$ and 3 $\mathrm{ml}$ ethanol. The solution was shaken until homogeneous and was incubated at $37^{\circ} \mathrm{C}$ for 30 minutes.

Table 2. Phytochemical screening results

\begin{tabular}{llccccc}
\hline & & \multicolumn{5}{c}{ Phytochemical screening } \\
\cline { 2 - 7 } \multicolumn{1}{c}{ Sample } & Alkaloid & Flavonoid & Tannin & Saponin & $\begin{array}{c}\text { Triterpe- } \\
\text { noid }\end{array}$ \\
\hline P. pulchrum & Roots & + & - & - & ++ & ++ \\
Blume & Stems & - & + & - & - & + \\
& Leaves & + & ++ & + & - & - \\
& Flowers & - & - & - & + & ++ \\
\hline
\end{tabular}

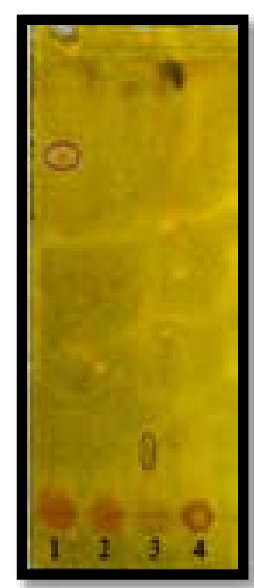

(a)

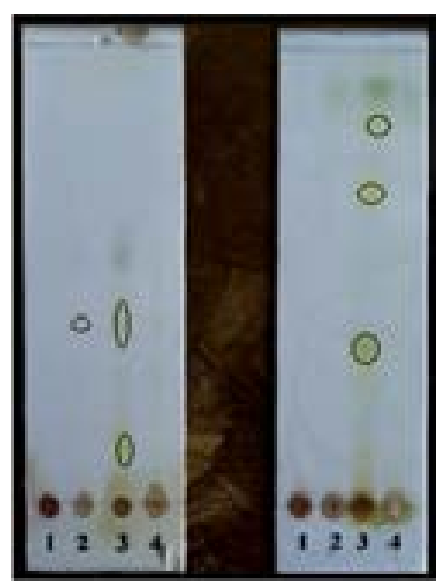

(b2)

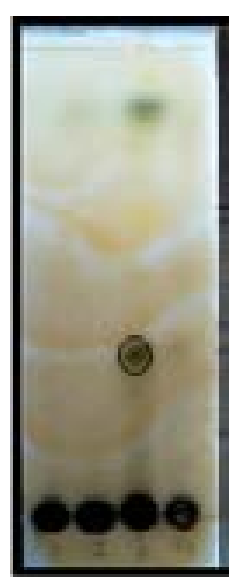

(c)

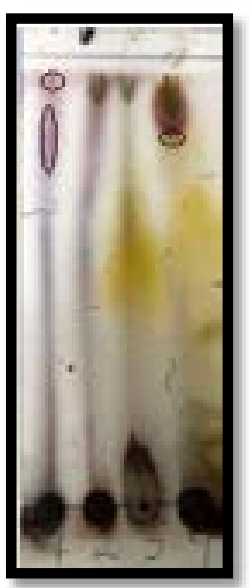

(d)

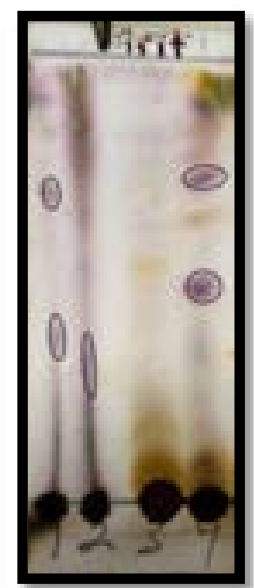

(e)

Figure 2. Phytochemical screening using TLC 
from the Faculty of Fisheries and Marine Sciences, Halu Oleo University, Indonesia.

\section{Extraction}

Maceration of plants was performed in a closed container for $3 \times 24$ hours using ethanol

Preparation of ethanol extract $1000 \mathrm{mg} / \mathrm{l}$

$50 \mathrm{mg}$ of roots, stems, leaves and flowers viscous extract were dissolved in $50 \mathrm{ml}$ of ethanol. Dilution was performed on $1000 \mathrm{mg} / \mathrm{l}$ sample to obtain $12.5,25,50,100$, and 200 $\mathrm{mg} / \mathrm{l}$ of samples. The solutions were shaken until homogeneous and were incubated at 37 ${ }^{\circ} \mathrm{C}$ for 30 minutes. The absorption test was performed at $515.5 \mathrm{~nm}$.

\section{Calculation}

All of the inhibition concentrations $\left(\mathrm{IC}_{50}\right)$ of DPPH radical from each sample was calculated using this formula:

$\%$ Inhibition $=\frac{\text { Blank Absorbance }- \text { Sample Absorbance }}{\text { Blank absorbance }} \times 100 \%$

\section{Results and Discussion}

Extraction

The extract was obtained using maceration with ethanol solvent. The yield of each extract was $3.6 \%, 5.1 \%, 3.24 \%$, and $2.3 \%$ for roots,

Table 3. \% inhibition of ethanol extract of $P$. pulchrum Blume

\begin{tabular}{lcccc}
\hline \multirow{2}{*}{ Sample } & \multicolumn{2}{c}{ Absorbance } & & \\
\cline { 2 - 5 } & Blank & Sample & Concentration (mg/l) & \% Inhibition \\
\hline \multirow{3}{*}{ Roots } & \multirow{2}{*}{0.7528} & 0.3799 & 12.5 & 49.54 \\
& & 0.3773 & 25 & 49.88 \\
& & 0.3768 & 50 & 49.95 \\
\hline Stems & 0.3319 & 0.3172 & 100 & 57.86 \\
& & 0.2820 & 200 & 62.54 \\
\hline Leaves & 0.3319 & 0.1863 & 12.5 & 43.86 \\
& & 0.1675 & 25 & 49.53 \\
& & 0.1610 & 50 & 51.49 \\
& & 0.1459 & 100 & 56.04 \\
& & 0.0617 & 200 & 81.41 \\
\hline Flowers & 0.7528 & 0.1913 & 12.5 & 42.36 \\
& & 0.1904 & 25 & 42.63 \\
& & 0.1859 & 50 & 43.98 \\
& & 0.1462 & 100 & 55.95 \\
& & 0.0813 & 200 & 75.50 \\
\hline Vitamin C & 0.4462 & 0.4761 & 12.5 & 36.75 \\
& & 0.4604 & 25 & 38.84 \\
& & 0.4514 & 50 & 40.03 \\
& & 0.4503 & 100 & 40.18 \\
& & 0.3667 & 200 & 51.28 \\
\hline
\end{tabular}




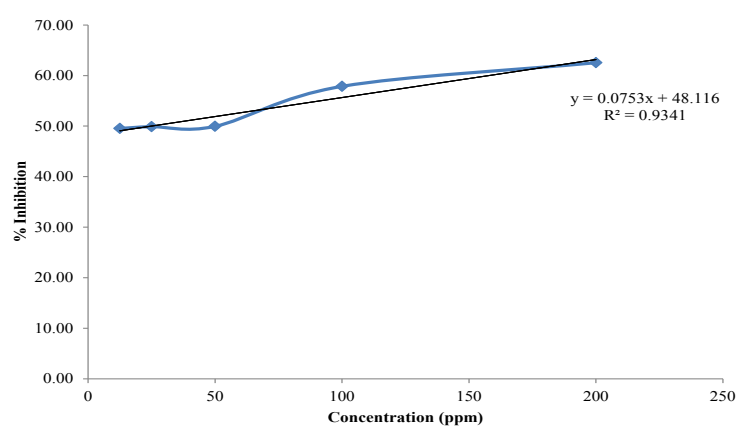

Figure 3. \% inhibiton of $P$. pulchrum Blume roots extract

stems, leaves, and flower extract, respectively (Table1).

\section{Phytochemical screening}

Phytochemical screening was performed to identify the secondary metabolites in the extract. We found that alkaloids, flavonoids, tannins, saponins, and triterpenoid were found in different parts of the plant (Figure 1, Table 1). Figure 2 shows the result of phytochemical screening indentification after reagent markers were sprayed into the TLC plate.

\section{Antioxidant activity}

Antioxidant activity testing aimed to determine the inhibiton concentration value $\left(\mathrm{IC}_{50}\right)$ of the extract using DPPH method.

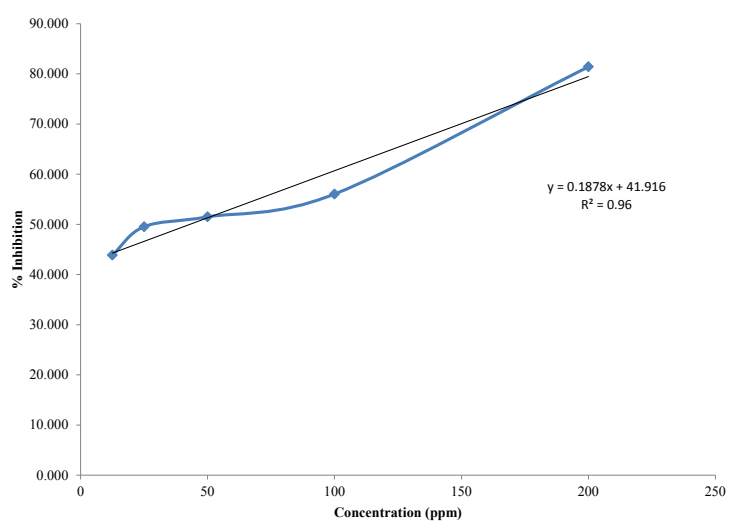

Figure 5. \% inhibiton of P. pulchrum Blume leaves extract

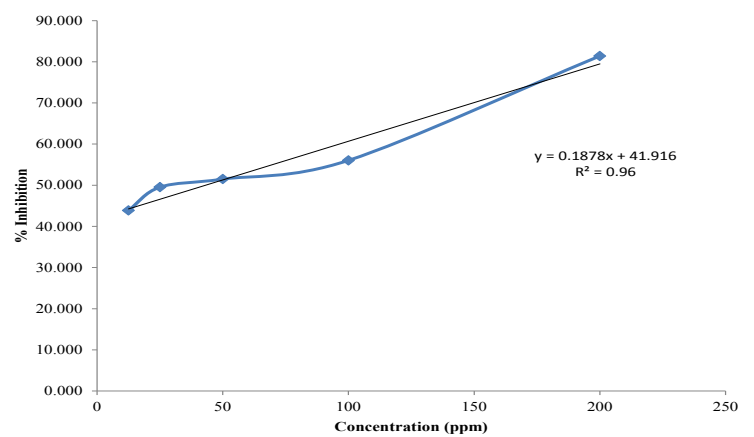

Figure 4. \% inhibition of P. pulchrum Blume stems extract

This method is based on the DPPH radicals color change which caused by the reaction between free radical of DPPH and one electron or hydrogen atom released from the compound contained in the extract to form a DPPH compound whose color is yellow. We compared the antioxidant activity of the extracts with vitamin $\mathrm{C}$ (Table 3 ).

Antioxidant activity increased in accordance with the rise of concentration. This was marked by the fading colour of DPPH and the greater percentage of inhibition value. After obtaining the inhibition percentages, the graphs between the sample concentration $(\mathrm{x})$ and the percentage of inhibition (y) was made. The results can be found in Figure 3-7.

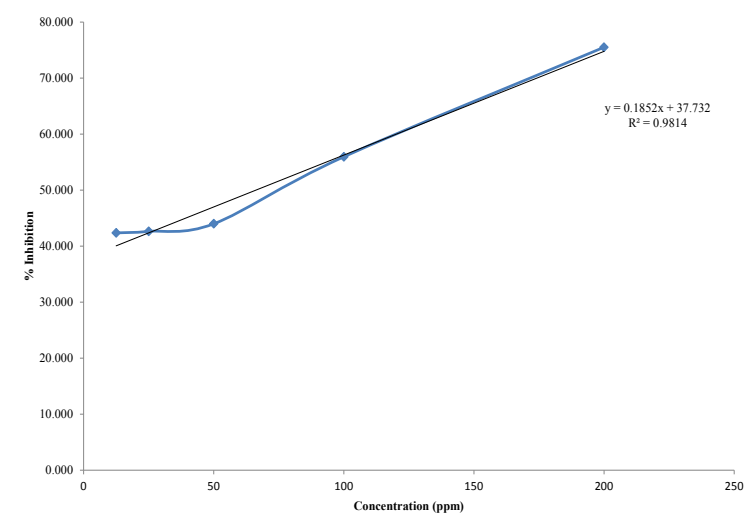

Figure 6. \% inhibiton of P. pulchrum Blume flowers extract 


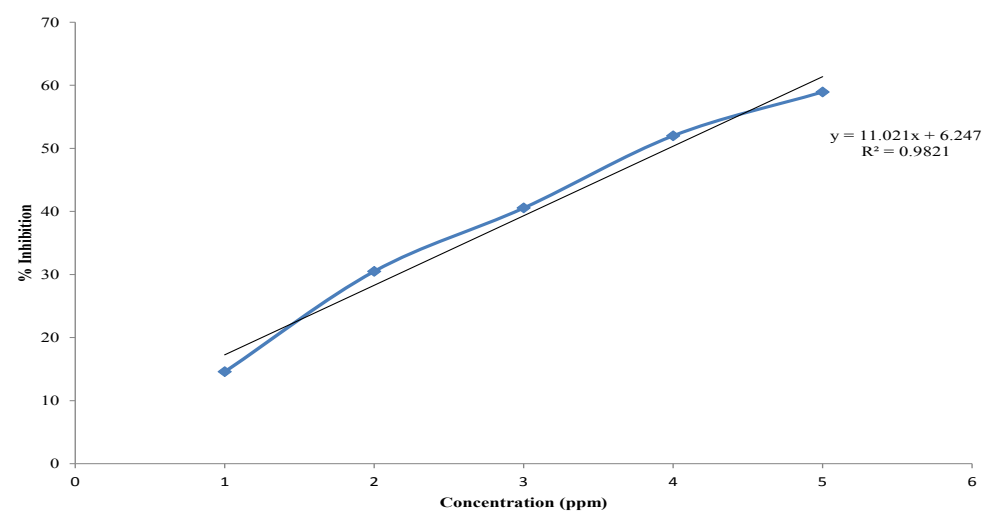

Figure 7. \% inhibition of vitamin $\mathrm{C}$

Table 4. $\mathrm{IC}_{50}$ values of ethanol extract

\begin{tabular}{cc}
\hline Sample & $\left.\mathbf{I C}_{\mathbf{5 0}} \mathbf{( m g} / \mathbf{l}\right)$ \\
\hline Roots & 25.2 \\
Stems & 43.26 \\
Leaves & 66.32 \\
Flowers & 202.96 \\
Vitamin C & 3.97 \\
\hline
\end{tabular}

The $\mathrm{IC}_{50}$ values can be determined using the linear regression equations. The smaller $\mathrm{IC}_{50}$ value the greater the antioxidant activity. IC50 value extract of roots, stems, leaves, flowers P. pulchrum Blume and vitamin C can be seen in Table 4 .

We found that ethanol extracts of P. pulchrum Blume roots and stems had strong antioxidant activity with $\mathrm{IC}_{50}$ values of $25.2 \mathrm{mg} / \mathrm{l}$ and $43.26 \mathrm{mg} / \mathrm{l}$, respectively. Flowers ethanol extract had the weakest antioxidant activity with $\mathrm{IC}_{50}$ value of $202.96 \mathrm{mg} / \mathrm{l}$. Vitamin $\mathrm{C}$ had very strong antioxidant activity with an $\mathrm{IC}_{50}$ value of $3.97 \mathrm{mg} / \mathrm{l}$. A compound can be said to be a very powerful antioxidant if the $\mathrm{IC}_{50}$ is less than $50 \mathrm{mg} / 1$, strong antioxidant if $\mathrm{IC}_{50}$ is between $50-100 \mathrm{mg} / \mathrm{l}$, moderate antioxidant if $\mathrm{IC}_{50}$ is between $100-150 \mathrm{mg} / \mathrm{l}$, weak antioxidant if $\mathrm{IC}_{50}$ value is between 150$200 \mathrm{mg} / \mathrm{l}$, and very weak antioxidant effect if $\mathrm{IC}_{50}$ value is more than $200 \mathrm{mg} / 1 .{ }^{9}$ High antioxidant activity in the ethanolic extract might be due to the presence of flavonoids, alkaloids, and triterpenoids. ${ }^{10-12}$

\section{Conclusion}

This study revealed that ethanol extract of $P$. pulchrum Blume roots and stems had strong antioxidant activity, therefore, this plant might be potential as an excellent source for natural antioxidant agents for medical application.

\section{Acknowledgement}

None.

\section{Funding}

None.

\section{Conflict of Interest}

None declared.

\section{References}

1. Nagmoti DM, Khatri DK, Juvekar PR, Juvekar AR. Antioxidant activity 
free radical-scavenging potential ofPithecellobium dulceBenth seed extracts. Free Radicals Antioxidants. 2012;2(2):37-43.

2. Alabd NM, Mohamed Nor Z, Mansor M, Azhar F, Hasan MS, Kassim M. Antioxidant, antibacterial activity, and phytochemical characterization of Melaleuca cajuputi extract. $B M C$ Complementary and Alternative Medicine. 2015;15:385.

3. Fawole OA, Makunga NP, Opara UL. Antibacterial, antioxidant and tyrosinaseinhibition activities of pomegranate fruit peel methanolic extract. $B M C$ Complementary and Alternative Medicine. 2012;12:200.

4. Srivastava RC. Family Polygonaceae In India. Indian Journal of Plant Sciences. 2014;3(2): 25-26.

5. Lv LS, Gu XH, Tang J, Ho CT. Antioxidant activity of stilbene glycoside from Polygomum multiflorum Thunb in vivo. Food Chemistry. 2007;104:16781681.

6. Lin HW, Sun MX, Wang YH, Yang LM, Yang YR, Huang N. Anti-HIV activities of the compounds isolated from Polygonum cuspidatum and Polygonum multiflorum. Planta Medicines. 2010;76:889-892.

7. Lee BH, Huang YY, Duh PD, Wu SC. Hepatoprotection of emodin and Polygonum multiflorum against $\mathrm{CCl}$ (4)-induced liver injury. Pharmaceutical
Biology. 2012;50:351-9

8. Pochapski MT, Fosquiera EC, Esmerino LA. Phytochemical screening, antioxidant, and antimicrobial activities of the crude leaves' extract from Ipomoea batatas (L.) Lam. Pharmacognosy Magazine. 2011;7(26):165-170.

9. Nariya PB, Bhalodia NR, Shukla VJ, Acharya R, Nariya MB. In vitro evaluation of antioxidant activity of Cordia dichotoma (Forst f.) bark. Ayurvedha. 2013;34(1):124-128.

10. Saeed N, Khan MR, Shabbir M. Antioxidant activity, total phenolic and total flavonoid contents of whole plant extracts Torilis leptophylla L. BMC Complementary and Alternative Medicine. 2012;12:221.

11. Choudhary RK, Swarnkar PL.Antioxidant activity of phenolic and flavonoid compounds in some medicinal plants of India. Natural Products Research. 2011;25:1101-1109.

12. Zang Z, Liu C, Xiang L, Zheng Y.Phenolic alkaloids as a new class of antioxidants in portulaca oleracea. Phytotherapy Research. 2009;23:1032-1035.

13. Kim YA, Kong CS, Lee Ji. Evaluation of novel antioxidant triterpenoid saponins from the halophyte Salicornia herbacea. Bioorganic and Medicinal Chemistry Letter. 2012;22:4318-4322. 